\title{
An Anthropological Approach to the Use of Medicinal Plants in the Treatment of Diseases: The Case of King Grass (Ageratum Conyzoides) in Batibo Subdivision in North West Region of Cameroon
}

\author{
${ }^{1}$ Mukum Cenotar Engwari, ${ }^{2}$ Ngoe Fritz Eseokwea (PhD), \\ ${ }^{3}$ Achu Frida Njiei (PhD) \\ ${ }^{I}$ Anthropologist/Researcher, National Centre for Education, \\ Ministry of Scientific Research and Innovations, Yaounde, Cameroon \\ ${ }^{2}$ Economist/ Researcher; National Centre for Education, \\ Ministry of Scientific Research and Innovations, Yaounde, Cameroon \\ ${ }^{3}$ Integrated Rural Development / Researcher, National Centre for Education, \\ Ministry of Scientific Research and Innovation, Yaounde, Cameroon
}

Article DOI: https://doi.org/10.36713/epra7496 DOI No: 10.36713/epra7496

\begin{abstract}
Batibo subdivision has several medicinal plants used in the treatment of diseases; among them is king grass, which has been used by traditional healers in the treatment of several diseases some of which have defied modern or orthodox medicines. This research examines the uses of king grass among herbalists or traditional healers in treatment of a wide spectrum of diseases which are believed to be attributed by both physical and spiritual causes. Data for the study was collected through documentation, interviews, observations, and group discussions. Results indicates that king grass has about seventeen uses for treatment of tropical diseases which have defied conventional approaches. However, the greatest handicap encountered by healers is their inability to harvest and preserve the plant in its fresh forms as preferred by the healers. Research for preservation of the plant in its fresh forms can save lives during season of scarcity. It is therefore necessary for government and its agencies to create an enabling environment for preservation of the plant than relying on seasons when it is made available. Research in postharvest for the plant will increase its availability and accessibility to actors as its life saving potentials will no longer be seasonal.

KEY WORDS: Anthropological Approach, Diseases, King grass, medicinal plants.
\end{abstract}

\section{INTRODUCTION}

African societies have used herbs to promote healing of many diseases in ways and approaches different from orthodox or modern medicines (Bussman, 2006). The availability of modern medicines has not prevented the use of indigenous knowledge systems in the treatment of diseases in most areas, a reason why herbalists practice this occupation even in urban areas where modern medicines are accessible and affordable. The use of herbs or medicinal plants in the treatment of diseases was identified long before the invention of modern medicines in Europe and America. As the European and American societies developed in science and technology less emphasis was placed in the use of raw herbs in the treatment of diseases (Reinaldo, 2001). On the contrary, herbal and traditional medicine was promoted in societies of Africa and Asia including South America which have not advanced significantly in modern medicines. Ngoe 
and Manu (2016) argues that African societies can never abandon traditional approaches to cures because there exist a myriad of diseases that cannot be treated by the use of orthodox medicines in both developed and developing countries. Both researchers further argue that modern medicine was developed from plants through solvent extractions from those plant components that had been identified by herbalists and tradi-practisioners in the treatment of diseases and that modern medicines cannot provide cure for most diseases and illnesses. According to Dewa (2002), every leaf or back of plants contains two components, the physical component where chemical elements constituting the plant could be identified in the laboratory and metaphysical components that cannot be identified in the laboratory. For example patients suffering from spiritual problems attributed to witchcraft and other supernatural causes can only be treated by a spiritualist using those components that cannot be identified in the laboratory. This may help to explain why most developing societies depend on medicinal plants for treatment of diseases. According to WHO (2009), about $80 \%$ of the populations of African countries depend on traditional medicines in the treatment of diseases and an integration of both modern and traditional or herbal cures into healthcare systems could provide a remedy for thousands of people who suffer from diseases that can only be treated by unorthodox means.

Plants provide the basis for the development of modern drugs and to ignore traditional medicine by laying emphasis on orthodox or modern medicines is failure on the part of governments and its agencies. It is for these reasons that the World Health Organisation (WHO) have been actively involved in programmes for the development of traditional or herbal cures since 1977. It is hoped that when the WHO programmes for medicinal plant development are introduced in Cameroon King Grass could be implicated due to its diverse uses in many parts of Cameroon; and Batibo subdivision in particular. King grass handles diverse diseases and also destroy disease symptoms before they could develop into devastating illnesses. According to Okoli et al., (2007), herbal practice on the African continent dates as far back as 4000 years and was the sole medical system of health care before the advent of modern medicine. In African societies the use of herbs like King grass (Ageratum Conyzoides) among other is widespread, providing cures for a wide spectrum of diseases. It is for these reasons patients suffering from diseases that defy modern medicines are evacuated to herbal homes where medicinal plants are used for treatment. In Cameroon medicinal plants have been used in the treatment of complications such as liver problems, kidney dysfunctioning, food poisoning, erectile problems including weak sexual drive, nervous diseases, bareness in men and women, hyernia, headaches, mental disorder, fevers(malaria, yellow fever, typhoid etc) and most diseases attributed to witchcraft and other supernatural causes that cannot be successfully handled by orthodox approaches.

Reinaldo, (2003: 7) writes:

There are many reasons from blind desperation to the active, positive search for a transformation that explain why people are willing to consult a herbalist or other alternative therapists. One strong motivation force of growing importance is the fear (imagined or real) of drugs and their side effects, as well as the traumatic effects of surgical operations.

However it has been observed that knowledge of medicinal plants is rapidly declining in some parts of Africa and Cameroon in particular due to deforestation which extincts plant species, changing life style attributed to westernization and urbanisation, reduction in the number of traditional healers due to loss of interest among the younger generations, and increasing use of modern health care facilities.

\section{Objectives of the study}

1. Identify the various agro-ecological areas where king grass can be found in Cameroon.

2. Identify the various types of diseases treated by the use of the king grass in Batibo Subdivision.

3. Examine the reasons for the decline in the use of medicinal plants in the study area.

\section{METHODOLOGY}

\section{Study area}

The study took place in the Moghamo clan in Batibo sub division, Cameroon. Moghamo clan is among the areas in the Northwest region where traditional approaches are highly practiced and respected by the people. The clan has reputable traditional practitioners who are said to have acquired the knowledge by divination and inheritance. Contrary to other places in the Cameroon, where the practice of traditional medicines has seen a decline, in Moghamo the use of traditional medicines has not declined significantly because modernisation and other factors have not affected the life style of the people. In contemporary Moghamo society people pride in the knowledge of traditional medicines is a way of life of the people. This is because most tradipractitioners in the clan have been handing over the knowledge of traditional medicines to other generations either through divinations or by inheritance. 


\section{The Location of Moghamo}

The Moghamo community is located between latitudes $4^{\circ} 95$, and $5^{\circ} 45$, North of the Equator and longitudes $10^{\circ} 10$, and $10^{\circ} 30$, East of the Greenwich Meridian Ayah P.A (2001). Moghamo enjoys both the equatorial rain forest agro-ecological zone and savannah vegetation. The equatorial rain forest area is situated in the South along the Mamfe-Bamenda high way between Widikum and Bali towns. Batibo, the head quarters of the Moghamo clan which also serves as administrative capital of Batibo subdivision, is located $40 \mathrm{~km}$ along the Bamenda Bali- Batibo Road with a surface area of about $415.9 \mathrm{~km}^{2}$ with a projected population of over 100.000 people, (Cameroon Population estimates, 2009). The Sub division is surrounded in the east by Momo division, south by Widikum subdivision, north west by Mbengwei subdivision and Bali subdivision and in the south west by Fontem subdivision in Libialem division.

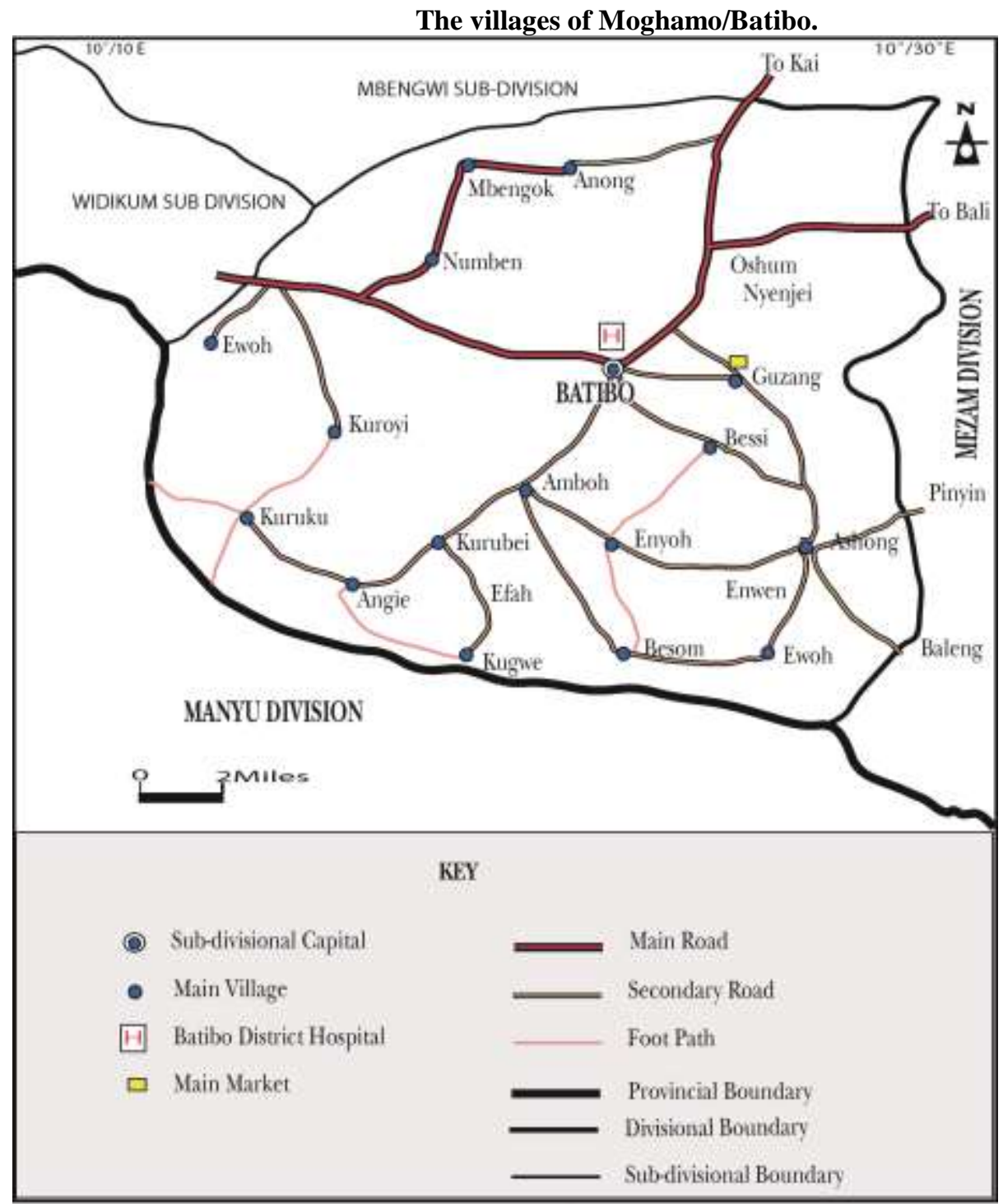

Source: Batibo Rural Council, (December, 2010) by Afu I. K. (2012: 39)

\section{DATA COLLECTION}

Sampling procedure

The study was conducted in twenty two villages of the Moghamo clan of Batibo subdivision. The villages were randomly selected in the clan because herbal or traditional practisoners are found in every village of the clan. Traditional healers were selected by purposive sampling because though every village in the Moghamo tribe practice herbal healing not everybody is involved in the practice.

Primary data sources

Primary data was collected by interviews guide, Focus Group Discussions (FGD), and direct 
observation of the activities of traditional healers in the treatment of patients by use of king grass. Direct observation also involved an identification of the areas where king grass is commonly found since not yet domesticated. These methods of data collection were used to maximize data credibility, reliability and validity in order to reduce chances of bias by investigators. Focus group discussions were conducted among the actors to understand group experience on medicinal plants and obtain more information on its uses.

\section{Secondary data sources}

Secondary data was gathered by documentation from existing works on medicinal plants and king grass in particular. This was obtained through scientific journals, text books, articles on websites and from institutional libraries such as: Faculty Arts, Letters, Social and Human Sciences of the University of Yaounde, the Botanical and Specialised Research Centre, Institute of Research in Agricultural Development(IRAD), Yaounde; Centre for Applied Social Science-Research and Training(CCAS-RT), the Batibo Rural Council Library(BRCCL), Cercle, Philo-Psyco-Socio-Anthropo(CPPSA), and Ministry of Scientific Research and innovation(MINRESI). Information from these sources was useful in understanding the uses of King grass beyond Batibo subdivision

\section{Data analysis and interpretation}

The qualitative method of the study was used in the interpretation of primary data. These were arranged according to the objectives. Data interpretation was done by the use of two theories, namely the ethnoperspective theory as well as the functionalism theory. The ethno perspective theory of Mbonji Edjenguèlè is characterized by three elements; holisticity, cultural endosemy and contexuality which were used to provide the uses of the king grass. The cultural endosemic focus holds that every society has inner meanings that it attaches to phenomena. The theory was used to get perceptions that people in the Batibo community have concerning the contribution of the king grass to health care system of people. The functionalist theory of Malinowski; specifically, Merton's notion of Hidden function and manifest function of king grass. According to the author's perception of functionalism, all standardized social and cultural beliefs and practices are functional for both the society as a whole as well as individuals in that society.

\section{RESULTS AND DISCUSSIONS \\ Areas of propagation of king grass.}

The study reveals that King grass is found almost everywhere in the rainforest zone of Batibo subdivision, especially in secondary forests and residential areas. It was found as a nuisance growing around buildings, residential homes, farms, garden, behind, some office buildings, streams and springs and moist sheltered places. The plant is commonly found during the wet than dry season as it withers and perishes during prolonged hot weather conditions. Under favorable conditions its leaves are green with soft stems which harden with maturity. During the dry season, the plant losses moisture when it is not sheltered under trees, canopy, or near water sources. It hardly grows where there is bahama grass. King grass bears white light flowers whose components are easily propagated by wind. Its leaves are soft and easy to crush by hands or mortar. King grass is among the few medicinal plants which are hardly consumed by other animals despite its diverse medicinal uses.

King grass is important in the treatment of diseases attributed to physical and supernatural causes. According to Fennel et al; (2004) king grass can equally be dangerous to the health of men and cautions that men weeding or harvesting king grass must always wash their hand before touching their male organs as it causes weak sexual drive as revealed by actors. These findings help to explain why women are more involved in weeding the grass than men as it has zero effect on the private organs of women as they hardly touch their private organs during urination.

\section{Identification of medicinal uses of king grass}

Respondents revealed that king grass is used to treat both supernatural and natural illnesses. It was further revealed that the plant is used in treating about seventeen natural illnesses/diseases in the study areas. The table below indicates the various types of diseases treated by king grass and part of the plant used. 
The Different illnesses/diseases treated by using the king grass

\begin{tabular}{|c|c|c|}
\hline Illnesses/diseases & $\begin{array}{l}\text { Part(s)/components } \\
\text { used for treatment }\end{array}$ & $\begin{array}{l}\text { Procedure for preparation /administration } \\
\text { to patients }\end{array}$ \\
\hline Frontal headache & Leaves & $\begin{array}{l}\text { Grind the leaf and apply on the fore head by } \\
\text { massaging. The patient is made to shake the } \\
\text { head continously during massaging }\end{array}$ \\
\hline Abscess & Leaves & $\begin{array}{l}\text { Warm the leaves on flames of fire from wood } \\
\text { (not gas) or on top of any hot object and } \\
\text { apply on the affected area. }\end{array}$ \\
\hline Sore throat & Leaves & $\begin{array}{l}\text { The fresh leaves are washed, chewed and } \\
\text { swallowed with the greenish juice/ chlorophyll. }\end{array}$ \\
\hline Diarrhea & Leaves & $\begin{array}{l}\text { Squeeze the leaves, extract the juice and } \\
\text { drink. }\end{array}$ \\
\hline Heart burn & Heads of the herb & $\begin{array}{l}\text { Squeeze } 7 \text { heads in half glass of water and } \\
\text { drink. }\end{array}$ \\
\hline Constipation & Leaves & Harvest 7 leaves and chew. \\
\hline Cataract (eye problems) & Leaves & $\begin{array}{l}\text { Extract the juice from the leaves and put in a } \\
\text { funnel made from plantain of banana leaves } \\
\text { and apply like eye drops. }\end{array}$ \\
\hline Ear problems & Heads of the herb & $\begin{array}{l}\text { The sap is extracted and mixed with grinded } \\
\text { alligator pepper and applied in the affected } \\
\text { ear through a traditional funnel. }\end{array}$ \\
\hline Typhoid & The whole plant & $\begin{array}{l}\text { The herb is put in decoction in the } \\
\text { preparation of a typhoid medicine, used in } \\
\text { drinking. }\end{array}$ \\
\hline Malaria & Leaves & $\begin{array}{l}\text { A decoction of the leaves with other herbs } \\
\text { and palm wine are prepared and used to } \\
\text { drink. }\end{array}$ \\
\hline Abdominal pain & Heads of the herb & $\begin{array}{l}\text { Boil four heads of the plant in } 4 \text { liters of } \\
\text { water and drink, } 1 / 2 \text { glass four times daily. }\end{array}$ \\
\hline Whitlow & Whole plant & $\begin{array}{l}\text { People suffering from whitlow should grind } \\
\text { both the king grass and alligator pepper and } \\
\text { apply on the affected finger for some time. }\end{array}$ \\
\hline Loss of Appetite & Whole plant & $\begin{array}{l}\text { Grind the leaves and add palm oil to make a } \\
\text { paste. Give it to infants half tea spoon full. }\end{array}$ \\
\hline Poison & $\begin{array}{l}\text { Leaves or heads of the } \\
\text { plant }\end{array}$ & $\begin{array}{l}\text { Chew seven leaves of the plant in } \\
\text { combination with seven seeds of alligator } \\
\text { pepper. }\end{array}$ \\
\hline Menstrual pains & Heads of the Plant & $\begin{array}{l}\text { Squeeze and drink the juice extracted from } \\
\text { the herb. }\end{array}$ \\
\hline Rheumatism & Heads of the plant & $\begin{array}{l}\text { Warm and mix with grind alligator pepper } \\
\text { and massage the affected part. }\end{array}$ \\
\hline Skin rashes & Heads of the plant & $\begin{array}{l}\text { Boil the herbs and use water to bath the } \\
\text { affected victim. }\end{array}$ \\
\hline
\end{tabular}

Source: Mukum Cenotar, (July 2014)

The above table shows that some diseases treated by stem, flowers and the roots in the treatment of diseases. king grass as well as the parts of the plants identified or Chin et al,(2006) puzzles how traditional healers implicated are treating the diseases. In this study it was identified the various parts of plants for treatment of observed that traditional healers have identified specific diseases while Funnel et al,(2004) are other opinion that parts of king grass for treatment of some diseases. scientific wisdom alone cannot unveal the mystery of Sometimes the whole plant could be used like the leaves, plant uses since some properties have been obtained 
through inheritance or handed down by divination.

Mofor, (2010) explains how herbs are used as Respondents also made mention on how the plant is preventives and cures by identifying common applied on the affected areas of a patient to ascertain the diseases that affecting man. Equally the ways of effectiveness of the plant in the treatment of specific using various herbs to combat ailments for illnesses diseases. It was revealed that when administering treated by use of king grass such as whitlow, treatment by use of the leaves of king grass emphasis is migraine or frontal headache and as well as laid on harvesting seven leaves of the plant. Other mystically oriented poison. In this study the studies and practices on use of seven leaves of king grass herbalists identified two categories of king grass, have different interpretation spiritually and physically namely, the male and female species. It was revealed depending on the tribe. In Batibo subdivision the that the female species of king grass is widely used in traditional healers revealed that the seven leaves used for the treatment of supernatural diseases like night treatment represent the seven gods of the Batibo land poison attributed to men having spiritual wives or both in the physical and spiritual realms. This revelation women having spiritual husbands with whom they implicating the gods is evidence that king grass has make love in dreams, spiritual or metaphysical world. physical and spiritual values for treatment of diseases. When these acts become rampant the victims become According to Wimbum C. (1988), the herbalists are of sexually impotent or may be involved in sex without the opinion that the gods do not accept even numbers of conception. The victims of nigh poisoning becomes leaves in the treatment of diseases as they do not like to unproductive and could visit clinical or modern share equal status with the physical world since their hospitals in their life time without solution unless contributions are greater for the treatment of diseases. they are introduced to a herbalist who knows the Healers believe that when treating with king grass it is solution to the problem. Another form of night the seventh leaf that links the patient to the spiritual poisoning revealed in the study is eating food in the world for treatment especially when the sickness has dream world. Victims of this type of night poisoning been attributed to supernatural forces. Such diseases are commonly identified with common diseases like require treatment beyond the physical realm.

This is in line with the works of Burkill, (1985) who investigated the usefulness of medicinal plants in aspects of therapy. According to the research the sap from fresh king grass leaves provides cures for chronic sores and for frontal headache. The same study revealed that sap from ageratum conyzoides leaves is used as pain killer during pregnancy; especially when there are difficulties to exit the foetus, and also in visual problems. Also, studies by Dewa, (2002) confirms and supports that ageratum conyzoides is used to treat hazy vision and eye pains. Respondents briefed on how to administer the herb to treat eye problems by squeezing the juice extract as eye drop. These uses have been confirmed in the field work experience on king grass as indicated on the table above.

In addition, Focho et al., (2009) reported that the leaves of the king grass can be chewed to remedy dysmenorrhoea a situation in women whereby they feel abdominal pains during menstruation. Focho recommends the chewing of fresh king grass leaves for women suffering from painful menstruation as solution to the problem.

Olatunji and Iranloye, (2008) in their findings reported that king grass has gastro- protective properties. Both researchers meant that king grass can be used in the treatment of gastric pains and can also be used as a means to prevent the illness. This is in line with our findings because Batibo people also use the ageratum conyzoides plant to treat people suffering from gastritis; when decocted with other medicinal herbs. fevers, headache, stomach disorder, body pains, and even erectile problems which become a common life phenomenon in them with no solution from the physical realm.

Foster and Anderson, (1978) writes that all societies have "Disease Theory Systems" to identify, classify and explain illnesses, their causes and remedies. Among the prominent theories supporting the "Disease Theory Systems" is the Personalistic Disease theory which attributes or associates diseases to the works of sorcerers, witches, ghosts, or ancestral spirits, and possession. Thus, in the Personalistic Disease theory illnesses are attributed to the work or acts of other people through supernatural beings. In accordance to this theory a victim could be sick as a result of jealousy and envy from other people or when the victims out of ignorance undermines supernatural laws and taboos that govern societies. Such taboos are most often disrespected or undermined by scholars of western orientation who often believe that all illnesses could be handled by orthodox or modern medicines. In this case, the causes and cure of these illnesses cannot be diagnosed and treated in the natural world. By this understanding, sufferers, their families, associations all participate to seek for solution from traditional healers who will use herbs with other objects like wooden bowls, rusted matchets, skulls of animals and in rare cases those of human beings for treatment of diseases. In Batibo, people suspected by their family members to be victims of strange diseases are taken to the herbalist or traditional doctors for treatment.

In this study the work of the herbalist had limitations due to his inability to show researchers 
the various ways of preventing diseases though respondents acknowledge that the diseases could be prevented. Generally, the Moghamo people do acknowledge that these diseases could be prevented by using king grass or by "cleansing"; a process whereby the herbalist uses other herbs to dispel spiritual forces responsible for the illness from the body of the victim. The pictures below shows the male and female species of king grass and also the treatment of ear diseases by use of king grass.

The Female and male king grass species
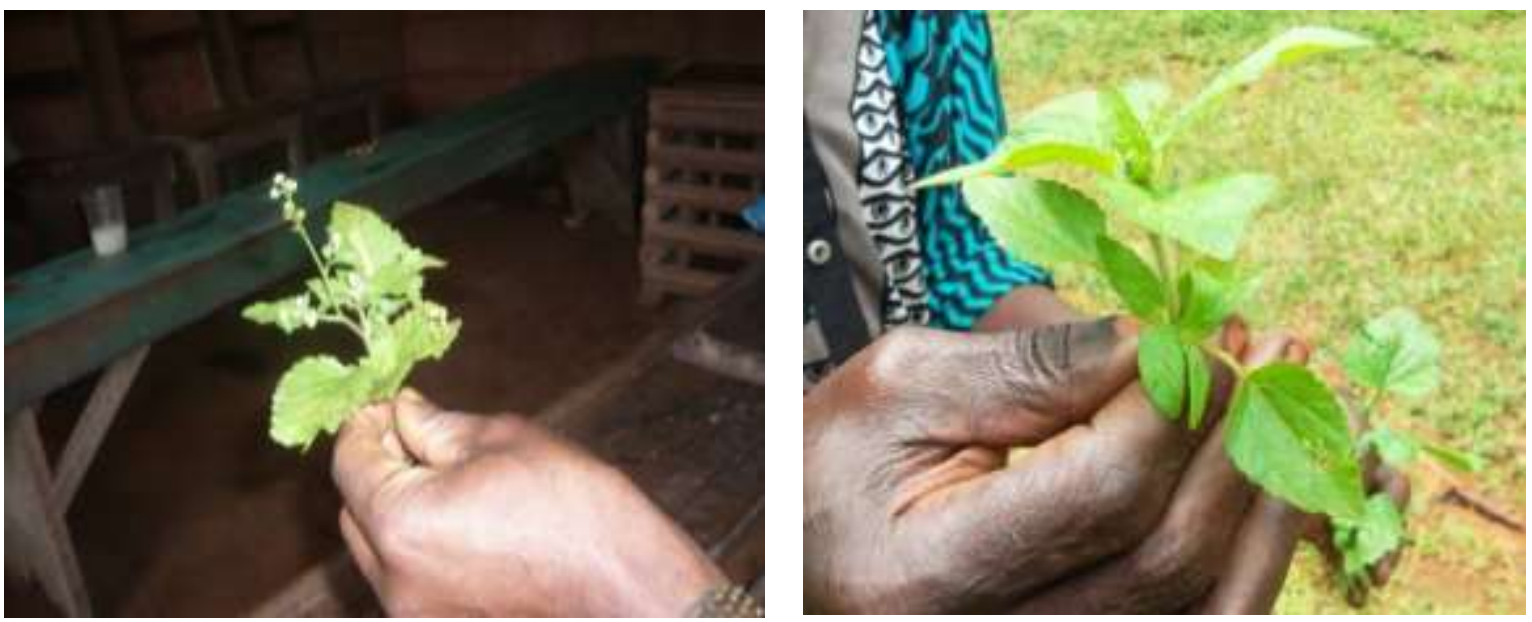

Source: Authors, (October 2017)

A herbalist using king grass in treating a patient from ear problems

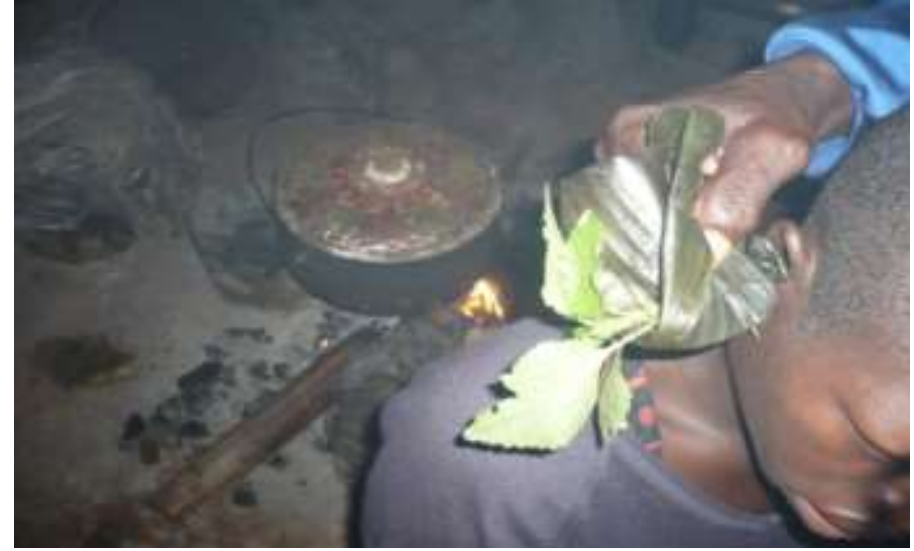

Source: Mukum Cenotar, (October 2017)

Mc Elroy and Townsend, (1989) laid emphasis on the fact that health and healing can be understood best in terms of the ethno medicine of a society while the insiders view is important to understand how an ethnic group defines and diagnoses diseases. He further explains:

Physicians in almost every part of the world have from time to time encountered a very special kind of patent the sorcery victim. This patient may believe that he or she has been attacked by a sorcerer or has broken on absolute taboo. No matter how the Western physician tries to treat the terrified patient, the patient believes that death is inevitable; becomes weaker each day and may actually die.

In this type of situation, only the tradi-practitioner has the last word concerning the patient's recovery or death since a medical doctor cannot be able to identify the real cause of the illness affecting the patient. The medical doctor may not be able to diagnose an illness from a patient suffering from a curse or mystical poison or the cause of bareness. According to Fennel et al; (2004) sickness attributed to spiritual causes can never be handled in western or orthodox treatment. According to the research the patient may even manifest the symptoms of ordinary diseases like malaria, headache, fevers and even body pains which could be treated by modern medicines 
but will never respond to treatment unless traditional cures are implicated. Most of the respondents explained that illnesses attributed to witchcraft often result during land disputes between friends, neighbours, relatives or brothers especially problems of succession and inheritance, abandoned traditional rites, as well as issues of jealousy. These results are in line with studies by Titus et al., (1979) are of the view that:

"The crucial sources of problems seem to be the impossibility of achieving fairness by the standards of all heirs and the impossibility of dividing some chattels and real estates equally"

This type of situation often results to jealousy among the contenders who most often seeks ways to punish others so that they can get much of the property by afflicting them with illnesses. Most often the contesting parties over inheritance may plant mystical poisons on the land for the concerned to die. Pauline (2002) attests that:

"Conflict over land underlies most of the disputes we face, and is central to the division of families and in effect turns family members into strangers".

With situations of this nature, it involves biases among contending parties which provokes anger and the spirit of vengeance while poisoning or killing are common amongst the people. Victims who fall sick as a result of these can only be treated by the traditional doctor using medicinal plants identified for the treatment of the inflicted diseases. Treatment by king grass together and other combination of plants is most often the remedy.

\section{Declining use of king grass and other medicinal plants}

This study indicates that in spite the overwhelming uses of king grass as remedy and cure for a wide spectrum of diseases there is growing fear that the practice of traditional cures may decline. Thus, putting future generations at risk in a subdivision where there are limited number of handicapped modern clinics, hospitals and where more than $80 \%$ of the population depend on traditional approaches to the treatment of diseases. These reasons are supported by study observation in various herbal homes implicated for the study. It was rather embarrassing that close to sixty percent of the herbal clinics were coordinated by men and women above seventy years of age while those who assisted them were men in their forties as revealed by the respondents. A few herbal homes were run by men who identified themselves among the late thirties and forty age brackets. There were few men and women in their twenties. This means that when the present generation of practitioners die or are made handicap by age the practice of traditional medicines will experience a steep decline that cannot be compromised. There will be limited number of people to engage in the practice as revealed by field work evidence. The following reasons were advanced by for future decline of traditional treatment by king grass amongst others.

1) The growing influence in the use of modern medicines for the treatment of diseases.

2) The regard of traditional practices as a hobby and not as profession as it was before colonial period when everybody was compelled to know the usage of plants.

3) The growing influence of religion and misconception about the use of herbs like king grass. Many missionaries and contemporary religious organisations are quick to condemn than investigate or understand certain practices like sorcery as paganism to Christian followers.

4) The growing influence of western education which does not warrant young people to stay at home and learn traditional practices with respect to medicines.

5) Government inability to integrate traditional medicines and modern medicines into the countries health care delivery system. Though the Cameroon government has issued licenses for people to practise traditional medicines, herbalists are often referred to as "charlatans" by their colleague of modern medicines.

6) Exploitative tendencies of most tradipractitioners.

Despite these causes of decline advanced by respondents we are still hopeful that the practice cannot be extinct knowing its importance in most rural communities.

\section{CONCLUSION}

Most communities fail to acknowledge that diseases can be caused by both natural and supernatural forces. As a result they depend solely on physical cures after diagnosis especially drugs from modern hospitals. They fail to understand that majority of illnesses could be attributed by both physical and spiritual causes. The people in Batibo strongly believe that both physical and spiritual forces are implicated in the causes of sickness in human beings. It is for these reasons that patients who cannot be treated by modern medicine or conventional means are referred to herbalists or traditional healers vested in identifying diseases attributed to supernatural forces like witchcraft, curses and taboos. This is because they believe that the healers have extensive knowledge about the use of herbs. As a result there exist values of trust, respect and confidentiality between the healers and 
the people of Batibo who are affected by these supernatural diseases. One of the greatest problems encountered with the use of king grass for herbal cures is that despite its importance in the treatment of diseases, there are growing fears that the knowledge about the plant could be extinct by generations of people. Thus, these people are not interested in promoting the uses of the plant despite its contribution as health remedy and cures in Cameroon and Batibo sub division in particular. It is widely known that spiritual values of medicinal plants are destroyed once the plants undergo industrial treatment in pharmaceutical industries.

It is for these reasons that one of the objectives of this study was to identify the uses of the plant so that researchers and herbalists may be vested with the wide spectrum of diseases the plant cures. Also there is need for scientists and medical researchers to integrate this plant species into mainstream research especially in areas like easing pains of delivery during child birth and reducing painful menstruation and other health problems. In addition there is need to sensitize youngsters on the knowledge of king grass especially as more than $80 \%$ of the population of the area depend on traditional remedies in the treatment of ailments It is hoped that this research will serve as source of information and data base for policy-makers, scientists, and farming communities to develop strategies for the development of the medicinal plant sector.

\section{REFERENCES}

1. Ayah, P.A, (2001). Elements for a History of the Moghamo Clan from Early Settlement-1916 Cameroon, Dissertation for Masters. FALSH, University of Yaounde 1.

2. Bi Holong.M., (1986) Contribution à l'etude de la Flore du Cameroun les Asteraceae. Thesis in Plant Biology. FASC, Université de Yaoundé 1.

3. Burkill, H.M., (1985). The Useful Plants of West Tropical Africa. $2^{\text {nd }}$ Edition, Royal Botanic Gardens, Kew. University Press of Virginia.

4. Bussman R. and Douglas S., (2006). Traditional Medicinal Plant Use in Northern Peru: Tracking Two Thousand Years of Healing Culture. J Ethnobiology Ethnomedine vol.2, pg46.

5. Butler M.S., (2005). Natural Products and Drugs: Natural Products Derived Compounds in Clinical trials. Natural products Rep 22:162-195.

6. Chin Y.W., Balunas M.J., H.B chai and A.D Kinghorn (2006). Drug Discovery from Natural Sources. Geneva.

7. Cunningham A.B., (1988). An Investigation of the Herbal Medicine Trade in Natal/Kwazulu Natal. Investigation Report No 29 Institute of Natural Resources, University of Natal, Pietermarizburg.

8. Focho D.A., EAP Nkeng, Lucha C.F., Ndam W.J., and Afegenui A., (2009). Ethnobothanical Survey of Plants used to Treat Diseases of the Reproductive System and Preliminary Phytochemical Screening of Some Species of
Malvaceae on Ndop. Journal of Medicinal Plants Research,3 (4), 301-314.

9. Foster G.M. and Anderson B.G., (1978). Medical Anthropology, New york

10. Funnel C.W., K.L. Lindsey., McGnaw L.J., Spang S.G., Statford G.I., Egorash E.E., Grace O.M., Van J., (2004). Assessing African Medicinal Plants for Efficacy and Safety: Pharmacological Screening and Toxicology. Journal of Ethnopharmacology, Elseiver.

11. Mbonji (2009). Santé, Maladies et Médecine Africaine. Plaidoyer pour l'Autre TradiPractique, Yaoundé, PUY.

12. Mbonji.E.(2005). L'Ethnoperspective ou La Méthode du Discours de L'Ethno-Anthropologie Culturelle, Yaoundé PUY.

13. Mc Elroy and Townsend P.K., (1985) Medical Anthropology in Ecological Perspective, Second Edition, Boulder Colorado U.S.A.

14. Mofor P. (2012). Natural Herbal and Preventive Medicine: A $21^{\text {st }}$ Century Health Guide for Every Home. Cameroon.

15. Ngoe Fritz Eseokwea and Manu Ibrahim(2017) : HIV/AIDS and Commercial Agricultural Sector in Cameroon: Impact, Vulnerability and Strategies to Reduce Prevalence Rates. International Review of Human and Social Sciences, Vol. 7, Number 7, February 2017.

16. Nkuinkeu.R. (1998). Plantes Médicinales et Exploitation Forestière. Les Produits Forestiers Non Ligneux en Afrique Centrale. Recherches Actuelles et Perspectives pour la Conservation et le Développement. FAO: Rome.

17. Nkwi. P.N., Nyamongo I.K. Gery, Wayne and Ryan, (2001). Field Research in to Socio Cultural Issues. Methodological Guidelines, Yaounde, Cameroon.

18. Odugbemi T. (2006). Outlines and Pictures of Medicinal Plants from Nigeria. University of Lagos Press.

19. Okoli C.O., Iwueke A.V., and Nwodo O.F.A., (2006). Evaluation of the Anti-Inflammatory and Analgesic Activities of Vitex Doniana Leaves. Afr J Biotech, 5(20):1929-1935.

20. Olatunji B. and Iranloye B.O., (2008). A Textbook of Medicinal Plants from Nigeria: Antiviral Properties of African Medicinal Plants. University of Lagos.

21. Pauline E.P, (2002) Bewitching Land: The Role of Land Disputes in Converting Kin to Strangers and in Class Formation in Malawi. Journal of Southern African States, Vol.28 pg 155-178.

22. Reinaldo G.S., (2003). Amazing Power of Healing Plants. Inter-American Division Publishing Association. Florida.

23. Titus, Sandra.L., Paul. C., Rosenblatt and Roxanne.M. Anderson. (2002). Family Conflict Over Inheritance of Property. JSTOR, Vol.28, No.3, pp.337-346.

24. Wimbum C., (1988). The Curative Plants of the Herb Doctor: Pharmacy, Macomb - 1993. Types of Medicinal Plants. Vol.3 relieves Bamenda.

25. World Health Organisation (1978). Traditional Medicine and Health Care Coverage: A Reader 
for Health Administratrators and Practitioners. Geneva.

26. World Health organisation (2002. Monographs on Selected Medicinal Plants, Vol. 2, World Health Organization, Geneva.

27. World Health Organisation (2003). Traditional Medicine. Fact sheet Number, 134, Geneva.

28. World Health Organisation (2003-2005). Traditional Medicine Strategies, Geneva. 